\title{
An Analysis of the Reasons of Internal Migration in Turkey with Logit Method
}

\author{
Serhat Yüksel (Corresponding author) \\ Head of Dept. of International Trade and Management, Konya Food and Agriculture \\ University, Meram, Konya, Turkey \\ E-mail: serhat.yuksel@gmail.com
}

\begin{abstract}
Suat Eroğlu
University of Kent, Brussels School of International Studies

E-mail: suateroglu1@gmail.com
\end{abstract}

Mustafa Özsarı

Dept. of Economics, Konya Food and Agriculture University

Meram, Konya, Turkey

E-mail: mustafa.ozsari@gidatarim.edu.tr

Received: Nov. 7, 2016 Accepted: Nov. 14, $2016 \quad$ Published: Nov. 23, 2016

doi:10.5296/bmh.v4i2.10350 URL: http://dx.doi.org/10.5296/bmh.v4i2.10350

\begin{abstract}
Internal migration refers to the situation in which people prefer to live in another city of the country because of the problems such as social, cultural and economic in the city they live. It was accepted that internal migration leads to some problems as imbalances in population distribution, irregular urbanization and unemployment in urban area. Owing to this situation, many countries try to take action so as to prevent this problem. Similar to this issue, the aim of this study is to determine influencing factors of internal migration in Turkey. Within this context, annual data of 81 cities for the period between 2008 and 2015 was used in this study. In addition to this aspect, panel logit method was used in order to achieve this objective. According to the results of the analysis, it was identified that high divorce rate is an important factor of internal migration in Turkey. Moreover, it was also determined that there is a positive relationship between this variable and internal migration. In addition to these
\end{abstract}


variables, Turkish people prefer to migrate from the cities that have high suicide rate. While taking into the consideration of this issue, it was recommended that Turkey should focus on social problems in the cities to minimize the problem of the migration.

Keywords: internal migration, Turkey, panel logit 


\section{Introduction}

Migration is one of the most important problems of the countries. While the definition of international migration is broad, internal migration has a narrow definition. Internal migration is a movement of an individual from one district to another within her/his own country (Castles, 2000). Looking at the direction, there are four types of internal migration, which are "rural-rural", "rural-urban", "urban-rural", "urban-urban" (Oucho \& Gould, 1993). Furthermore, there are voluntary and forced migrations depending on the causes (Wood, 1994). While former refers to a migration for seeking a better living conditions, latter refers to a migration which occurs because of a government policy or a rapid change in the living conditions in an area. Additionally, there are temporary and permanent migrations, as well.

People have economic, social, cultural, political, educational and environmental reasons to migrate (Çatalbaş \& Yarar, 2015). Most of the people migrate because of job-seeking activities (Lucas, 1997). Moreover, people may migrate because of lack of infrastructure, good-quality-schools, health services, parks and green-fields, public transportation services and so forth. People may also migrate because of personal reasons, such as education level, tolerance, age, marriage, family ties, skills and qualifications. In brief, people generally migrate when they are not able to satisfy their desires in their place of residence.

Internal migration has important impacts on economy and society. One of most important adverse effects of migration is imbalances in regional development. Due to the internal migration problem, some regions can develop effectively while some others cannot. The main reason behind this situation is that the amount of investments will be very low in the countries which have high migration rate (Molloy et al., 2011). Moreover, unemployment is another problem of the internal migration. Unemployment rates go up in the cities owing to increasing number of immigrant people who participate labor force. In addition to these reasons, internal migration also causes imbalances in population distribution in the country. Because of the migration, some cities will be overcrowded whereas population in some other cities will be very low (Çatalbaş \& Yarar, 2015).

On the other side, internal migration is also an important problem for Turkey. Many Turkish people who live in rural cities prefer to migrate to metropolises. Because of this situation, problems that were emphasized above are also essential for Turkey. As an example, according to Turkish Statistical Institute, the population of the biggest 3 cities (out of 81 cities) constitutes about $25 \%$ of total population in Turkey. On the other side, unemployment is another problem for Turkey mainly caused by internal migration. Owing to these aspects, it can be said that internal migration problem should be solved. For this purpose, firstly, the reasons behind these problems should be identified.

While taking into the consideration of these issues, it was defined that studies related to internal migration is very important. Owing to this situation, the aim of this study is to identify the influencing factors of internal migration in Turkey. Within this scope, the data of 81 cities of Turkey for the years between 2008 and 2015 was analyzed. As a result of this analysis, it will be possible to make recommendation in order to prevent this problem. 
The paper is organized as follows: after introduction part, we give detailed information about the studies that analyzed internal migration in the literature. In addition, the third part gives information about research and application so as to define the key factors that affect internal migration. Finally, the results of the analysis are given in the conclusion part.

\section{Literature Review}

Internal migration is a significant concept for many researchers. Due to this condition, there are a lot of studies in the literature related to this topic. Some of these studies were detailed on table 1.

Table 1. Similar studies in the literature

\begin{tabular}{|c|c|c|c|}
\hline Author & Scope & Method & Result \\
\hline Connell et al. (1975) & Village Areas & Survey & $\begin{array}{l}\text { Income distribution is the main determinant of the } \\
\text { internal migration. }\end{array}$ \\
\hline $\begin{array}{l}\text { Winer \& Gauthier } \\
\text { (1982) }\end{array}$ & Canada & Regression & $\begin{array}{l}\text { It was defined that there is a relationship between tax } \\
\text { and internal migration. }\end{array}$ \\
\hline Tanfer (1983) & Turkey & Survey & $\begin{array}{l}\text { Slower growth of agricultural production contributed } \\
\text { to increased internal migration movement. }\end{array}$ \\
\hline Oberai et al. (1989) & India & $\begin{array}{l}\text { Descriptive } \\
\text { Statistics }\end{array}$ & $\begin{array}{l}\text { Education, employment, technology and productivity } \\
\text { and civic amenities lead to internal migration. }\end{array}$ \\
\hline Brown (1997) & Russia & $\begin{array}{l}\text { Descriptive } \\
\text { Statistics }\end{array}$ & $\begin{array}{l}\text { Higher average wages and lower prices positively } \\
\text { affect in-migration. }\end{array}$ \\
\hline Oucho (1998) & $\begin{array}{l}\text { Sub-Saharan } \\
\text { Africa }\end{array}$ & Regression & $\begin{array}{l}\text { Demographic, political, economic, and social } \\
\text { perspectives are the main determinants of the internal } \\
\text { migration. }\end{array}$ \\
\hline Jorgji \& Gjipali (2001) & Albania & Probit & $\begin{array}{l}\text { They concluded that income differences affect the } \\
\text { internal migration. }\end{array}$ \\
\hline Cebula (2005) & World & $\begin{array}{l}\text { Descriptive } \\
\text { Statistics }\end{array}$ & $\begin{array}{l}\text { It was determined that higher unemployment rate } \\
\text { influences migration. }\end{array}$ \\
\hline Pazarlığlu (2007) & Turkey & Probit & $\begin{array}{l}\text { The main determinant of internal migration to Izmir } \\
\text { is related with the origins of people. }\end{array}$ \\
\hline $\begin{array}{l}\text { Gökhan \& Filiztekin } \\
\text { (2008) }\end{array}$ & Turkey & $\begin{array}{l}\text { Extended } \\
\text { Gravity Model }\end{array}$ & $\begin{array}{l}\text { Economic factors such as income differentials and } \\
\text { unemployment rates, and social factors such as } \\
\text { presence of social networks positively affect internal } \\
\text { migration. }\end{array}$ \\
\hline Gezici \& Keskin (2008) & Turkey & Regression & Regional inequalities cause the internal migration. \\
\hline $\begin{array}{l}\text { Gimba \& Kumshe } \\
\text { (2012) }\end{array}$ & Italy & Survey & $\begin{array}{l}\text { They reached a conclusion that educational, social } \\
\text { and technological factors influence internal } \\
\text { migration. }\end{array}$ \\
\hline
\end{tabular}




\begin{tabular}{|c|c|c|c|}
\hline Yakar (2012) & Turkey & $\begin{array}{l}\text { Correlation } \\
\text { Analysis }\end{array}$ & $\begin{array}{l}\text { It was identified that population growth is an } \\
\text { important factor that affects internal migration. }\end{array}$ \\
\hline Çoban (2013) & Turkey & $\begin{array}{l}\text { Descriptive } \\
\text { Statistics }\end{array}$ & $\begin{array}{l}\text { As the degree of disparity in terms of socioeconomic } \\
\text { and industrial development increases between the } \\
\text { urban and the rural areas, individuals become more } \\
\text { likely to migrate. }\end{array}$ \\
\hline Beine \& Parsons (2015) & $\begin{array}{l}\text { OECD } \\
\text { countries }\end{array}$ & Regression & $\begin{array}{l}\text { They identified that climatic factor does not have an } \\
\text { effect on internal migration. }\end{array}$ \\
\hline Strobl \& Valfort (2015) & Uganda & Regression & $\begin{array}{l}\text { They determined that there is a relationship between } \\
\text { unemployment and internal migration. }\end{array}$ \\
\hline Bhagat (2016) & India & $\begin{array}{l}\text { Descriptive } \\
\text { Statistics }\end{array}$ & $\begin{array}{l}\text { It was concluded that decrease in job opportunities } \\
\text { causes internal migration. }\end{array}$ \\
\hline Abdulai (2016) & Ghana & Probit & $\begin{array}{l}\text { It was identified that the main reason of internal } \\
\text { migration is related to the economic reasons. }\end{array}$ \\
\hline Piras (2016) & Italy & Gravity Model & $\begin{array}{l}\text { It was determined that macroeconomic variables are } \\
\text { the main reasons of the internal migration. }\end{array}$ \\
\hline Song \& Liang (2016) & China & Survey & $\begin{array}{l}\text { They reached a conclusion that there is a relationship } \\
\text { between international migration and internal } \\
\text { migration. }\end{array}$ \\
\hline Lucas (2016) & $\begin{array}{l}\text { Sub-Saharan } \\
\text { Africa }\end{array}$ & $\begin{array}{l}\text { Descriptive } \\
\text { Statistics }\end{array}$ & $\begin{array}{l}\text { It was defined that social and educational factors } \\
\text { affect internal migration. }\end{array}$ \\
\hline Mastrorillo et al. (2016) & South Africa & Regression & $\begin{array}{l}\text { It was determined that increases in positive } \\
\text { temperature increases out-migration. }\end{array}$ \\
\hline $\begin{array}{l}\text { Darlington-Pollock et } \\
\text { al. (2016) }\end{array}$ & England & $\begin{array}{l}\text { Descriptive } \\
\text { Statistics }\end{array}$ & $\begin{array}{l}\text { They identified that there is a relationship between } \\
\text { internal migration with health and social factors. }\end{array}$ \\
\hline
\end{tabular}

Some studies in the literature focused on the economic factors regarding internal migration. Jorgji \& Gjipali (2001) analyzed this problem in Albania. According to the results of the probit analysis, it was identified that income differences affect the internal migration. Additionally, Connell et al. (1975) and Gökhan \& Filiztekin (2008) reached a conclusion that income distribution is the main determinant of the internal migration. Furthermore, Cebula (2005) and Strobl \& Valfort (2015) determined that higher unemployment rate influences migration.

Moreover, social factors were taken into the consideration in some other studies (Darlington-Pollock et al., 2016), (Oucho, 1998), (Çoban, 2013). Furthermore, Oberai et al. (1989), Lucas (2016) and Gimba \& Kumshe (2012) identified that educational factors lead to internal migration. Additionally, Mastrorillo et al. (2016) made a regression analysis for the migration problem in South Africa. As a result of this analysis, it was concluded that climatic factor influences internal migration. On the other hand, Beine \& Parsons (2015) reached a 
conclusion that this factor is not effective for the migration problem in OECD countries.

In addition to those factors, there are also some studies which emphasized other reasons related to internal migration. Song \& Liang (2016) analyzed the migration problem in China and concluded that there is a relationship between international migration and internal migration. Also, Yakar (2012) defined that population growth is an important factor that affects internal migration. On the other side, Tanfer (1983) reached a conclusion that the main determinant of internal migration is slower growth of agricultural production.

\section{Analysis Results}

\subsection{Data Set}

In this study, we aimed to determine the influencing factors of internal migration in Turkey. Within this context, annual data of 81 cities for the period between 2008 and 2015 was used in this study. This data was provided from the website of Turkish Statistical Institute.

\subsection{Panel Logit Method}

Logit method is a type of a regression model in which dependent variable takes two different alternatives, such as "yes-no". In this analysis, logistic distribution function is used in order to satisfy this requirement. The details of this function are given on the following equation.

$$
\left.F\left(Y_{i}\right)=1 /\left(1+e^{-Y i}\right)=1 /\left(1+e^{-(B 0+B i X i+\varepsilon i}\right)\right)
$$

In this equation, " $Y$ " demonstrates the dependent variable. On the other side, " $\mathrm{X}$ " represents independent variables. In addition to them, " $\mathrm{B}$ " shows the coefficient of the independent variables. Moreover, " $\varepsilon$ " refers to the error term in the analysis. Furthermore, the term " $e$ " is equal to 2.72. Since it is positive, the value of the equation will be positive as well. Additionally, because it is on the denominator, the value of this equation will be less than " 1 ". In other words, by using logistic distribution function, dependent variable will take the value between "0" and "1" (Feder \& Just, 1977).

\subsection{Variables}

Since the aim of the study is to determine the reasons of internal migration, as a dependent variable, we used the number of net migration that is calculated by the difference between the numbers of in-migration and out-migration. If this number is positive for a city, dependent variable for this city was considered as " 1 ". On the other hand, when the number of net migration is negative, dependent variable took the value of " 0 ". Additionally, we used 13 different explanatory variables in this study so as to define the factors that affect internal migration. The details of these variables were given on table 2 . 
Table 2. Details of independent variables

\begin{tabular}{|l|l|}
\hline Concept & Variables \\
\hline \multirow{4}{*}{ Social } & Infant Mortality Rate \\
\cline { 2 - 2 } & Crime Rate \\
\cline { 2 - 2 } & Divorce Rate \\
\cline { 2 - 2 } & Suicide Rate \\
\hline \multirow{4}{*}{ Culture } & Number of Cinema \\
\hline \multirow{4}{*}{ Health } & Number of Classes in the City \\
\cline { 2 - 2 } & The Number of Teachers \\
\cline { 2 - 2 } & The Number of Schools in the City \\
\cline { 2 - 2 } Transportation & The Rate of Illiteracy \\
\hline \multirow{2}{*}{ Economic } & Number of Beds in the Hospital \\
\hline & The Number of Planes \\
\hline & Number of Buildings in the City \\
\cline { 2 - 2 } & Unemployment Rate in the City \\
\hline
\end{tabular}

As it can be understood from table 2, we used 13 different independent variables for 6 different concepts. With respect to the social factors, there are 4 different variables which are infant mortality rate, crime rate, divorce rate and suicide rate. Because these are negative factors, it was expected that there is an increase in internal migration when these ratios are high. Moreover, regarding cultural factor, we considered the number of the cinemas in the city. If this number is high, this means that this city is developed, so there should be positive relationship between them.

In addition to these variables, as for educational factors, there are 4 different variables which are number of classes in the city, number of teachers, number of schools and the rate of illiteracy. The first three variables of educational factors show the development in the education, so internal migration is expected to decrease when these ratios are high. On the other side, illiteracy ratio refers to the rate of the people who cannot read and write. Owing to this situation, if this ratio is high, internal migration from this city is expected to go up.

Furthermore, with respect to the health factor, the variable of the number of beds in the hospital is considered. If this number is high, this situation shows the improvement in health service, so people do not prefer to migrate from this city. Also, the number of planes that taken off or landed in a year in the city was taken into the consideration. Because this number shows the improvement in transportation sector, there should be negative relationship between this variable and internal migration.

Additionally, with respect to the economic factors, there are two different independent variables which are the number of buildings and unemployment rate in the city. Since the number of buildings refers to the development in construction sector, there should be an inverse relationship between this variable and internal migration. In addition to this variable, unemployment rate in the city was also considered as for economical factor. Within this 
context, when unemployment rate is high, people do not want to live in this city. In other words, there should be positive relationship between unemployment rate and internal migration.

\subsection{Analysis Results}

First of all, we made unit root test of the independent variables in order to understand whether they are stationary or not. Within this context, we made Augmented Dickey Fuller (ADF) unit root test. The details of this test were given on table 3.

Table 3. ADF Unit root test results

\begin{tabular}{|l|l|}
\hline Variables & Level Value (Prob) \\
\hline Infant Mortality Rate* & 0.091 \\
\hline Number of Buildings in the City* & 0.989 \\
\hline Number of Cinema* & 0.213 \\
\hline Number of Classes in the City* & 0.998 \\
\hline Crime Rate* & 0.999 \\
\hline Divorce Rate* & 0.524 \\
\hline Number of Beds in the Hospital & 0.001 \\
\hline The Rate of Illiteracy & 0.000 \\
\hline The Number of Planes & 0.002 \\
\hline The Number of Schools in the City* & 0.994 \\
\hline Suicide Rate & 0.002 \\
\hline The Number of Teachers* & 0.999 \\
\hline Unemployment Rate in the City & 0.000 \\
\hline
\end{tabular}

Note. *The first differences of these variables were used in the analysis.

As it can be seen from table 3 , probability values of 8 variables are more than 0.05 . This situation shows that these variables are not stationary on their level values. Because of this issue, the first differences of these variables were used in panel logit analysis. The details of logit analysis were demonstrated on table 4.

Table 4. Panel logit test results

\begin{tabular}{|l|l|l|}
\hline Variables & Coefficient & P Values \\
\hline Number of Buildings in the City & 5.540 & 0.1069 \\
\hline Number of Classes in the City & 8.710 & 0.6292 \\
\hline Divorce Rate & $2,011.357$ & 0.004 \\
\hline The Rate of Illiteracy & 46.373 & 0.007 \\
\hline The Number of Schools in the City & -0.001 & 0.407 \\
\hline Suicide Rate & 210.539 & 0.000 \\
\hline Unemployment Rate in the City & -0.035 & 0.1612 \\
\hline
\end{tabular}


In panel logit analysis, we had to eliminate 6 explanatory variables from the model because of the multicollinearity problem. As it can be understood from table 4, p values of 3 independent variables (divorce rate, the rate of illiteracy and suicide rate) are less than 0.05 . This means that these variables are statistically significant so as to explain the reasons of internal migration of Turkey.

First of all, it was determined that there is a direct relationship between internal migration and the variable of divorce rate due to the positive coefficient $(2,011.357)$. Because divorce rate is an indicator of the happiness for a city, people prefer to migrate to other cities when this ratio is high. In addition to this variable, it was also identified that there is a positive relationship between the rate of illiteracy and internal migration. This aspect refers that Turkish people prefer to migrate from their cities in which the proportion of illiterate people is very high. In other words, they want to live in the cities that have a low ratio of illiteracy.

Finally, it was also defined that the coefficient of the variable of suicide rate is positive (210.539). This condition explains that there is a direct relationship between this variable and internal migration. The main reason behind this situation is that higher suicide rate shows that there are lots of unhappy people in the city because it is a significant indicator of the happiness. That is to say, people in Turkey do not want to live in the cities in which the suicide ratio is high.

\section{Conclusion}

In this study, we tried to identify the reasons of internal migration. Within this scope, annual data of 81 different cities of Turkey for the period between 2008 and 2015 was analyzed. In addition to this situation, 13 different explanatory variables were taken into the consideration. Moreover, panel logit method was used in order to achieve this objective.

First of all, we made unit root test to the independent variables so as to determine whether they are stationary or not. Within this context, Augmented Dickey Fuller (ADF) unit root test was used. As a result, it was defined that 8 variables are not stationary on their level values. Owing to this situation, the first differences of these variables were used in the analysis.

According to the results of panel logit analysis, it was concluded that 3 different independent variables influence the people to migrate other cities of Turkey. First of all, it was defined that high divorce rate is an important factor of internal migration in Turkey. In other words, Turkish people do not like living in the cities in which divorce rate is high.

Another influencing factor of internal migration in Turkey is the rate of illiteracy. It was determined that there is a positive relationship between this variable and internal migration. The main reason behind this situation is that Turkish people prefer to live in the cities in which the proportion of illiterate people is low.

The last important factor that affects Turkish people to migrate is the suicide rate. It was identified that there is a direct relationship between this variable and internal migration. In other words, Turkish people prefer to migrate from their cities that have high suicide rate. The main reason for this condition is that suicide rate is a significant indicator of the 
happiness.

Internal migration causes some problems for the country. It mainly leads to imbalances in population distribution. In addition to this problem, it also increases unemployment in urban area of the country. By considering these issues, it can be understood that the problem of internal migration should be prevented. In this study, there main factors that affect the internal migration in Turkey were determined. Therefore, important points emphasized in this study will be directive to solve these problems.

\section{References}

Abdulai, A. M. (2016). Internal Migration Determinants: Evidence from Northern Region of Ghana. Ghana Journal of Development Studies, 13(1), 1-17. http://dx.doi.org/10.4314/gjds.v13i1.1

Beine, M., \& Parsons, C. (2015). Climatic Factors as Determinants of International Migration. The Scandinavian Journal of Economics, 117(2), 723-767. https://doi.org/10.1111/sjoe.12098

Bhagat, R. B. (2016). Changing Pattern of Internal Migration in India. Contemporary Demographic Transformations in China, India and Indonesia (pp. 239-254). New York: Springer International Publishing.

Brown, A. N. (1997). The Economic Determinants of Internal Migration Flows in Russia during Transition. The Davidson Institute Working Paper Series No. 89. [Online] Available: https://ssrn.com/abstract $=64508$

Castles, S. (2000). International Migration at the Beginning of the Twenty-First Century: Global Trends and Issues. International Social Science Journal, 52(165), 269-281. https://doi.org/10.1111/1468-2451.00258

Çatalbaş, G. K., \& Yarar, Ö. (2015). Türkiye'deki Bölgeler Arasi İç Göçü Etkileyen Faktörlerin Panel Veri Analizi İle Belirlenmesi. Alphanumeric Journal, 99.

Cebula, R. J. (2005). Internal Migration Determinants: Recent Evidence. International Advances in Economic Research, 11(3), 267-274. https://doi.org/10.1007/s11294-005-6656-8

Çoban, C. (2013). Different Periods of Internal Migration in Turkey from the Perspective of Development. American International Journal of Contemporary Research, 3(10).

Connell, J., Dasgupta, B., Laishley, R., \& Lipton, M. (1975). Migration from Rural Areas: The Evidence from Village Studies. University of Sussex, Institute of Development Studies, Discussion Paper no. 39

Darlington-Pollock, F., Norman, P., \& Ballas, D. (2016). Using Census Microdata to Explore the Inter-relationships Between Ethnicity, Health, Socioeconomic Factors and Internal Migration.

Feder, G., \& Just, R. E. (1977). A Study of Debt Servicing Capacity Applying Logit Analysis. Journal of Development Economics, 4(1), 25-38. https://doi.org/10.1016/0304-3878(77)90004-9 
Gezici, F., \& Keskin, B. (2005, August). Interaction between Regional Inequalities and Internal Migration in Turkey. In 45th Congress of the European Regional Science Association: Land Use and Water Management in a Sustainable Network Society, Amsterdam (pp. 23-27).

Gimba, Z., \& Kumshe, M. G. (2012). Causes and Effects of Rural-urban Migration in Borno State: A Case Study of Maiduguri Metropolis. Asian Journal of Business and Management Sciences, 1(1), 168-172.

Gökhan, A., \& Filiztekin, A. (2008). The Determinants of Internal Migration in Turkey. In International Conference on Policy Modelling (EcoMod 2008), Berlin, Germany.

Jorgji, E., \& Gjipali, A. (2001). Internal Migration in Albania: Analysis of Determinants Through a Self-selection Model. IHSN Working Paper.

Lucas, R. (2016). Internal Migration in Developing Economies: An Overview (No. id: 8818).

Mastrorillo, M., Licker, R., Bohra-Mishra, P., Fagiolo, G., Estes, L. D., \& Oppenheimer, M. (2016). The Influence of Climate Variability on Internal Migration Flows in South Africa. Global Environmental Change, $\quad 39, \quad 155-169$. http://dx.doi.org/10.1016/j.gloenvcha.2016.04.014

Molloy, R., Smith, C. L., \& Wozniak, A. (2011). Internal Migration in the United States. The Journal of Economic Perspectives, 25(3), 173-196. https://doi.org/10.1257/jep.25.3.173

Oberai, A. S., Prasad, P. H., \& Sardana, M. G. (1989). Determinants and Consequences of Internal Migration in India: Studies in Bihar Kerala and Uttar Pradesh.

Oucho, J. O. (1998). Recent Internal Migration Processes in Sub-Saharan Africa: Determinants Consequences and Data Adequacy Issues. In: Migration, Urbanization, and Development: New Directions and Issues, edited by Richard E. Bilsborrow. New York, New York, United Nations Population Fund [UNFPA], 89-120. https://doi.org/10.1007/978-94-011-4852-8_3

Oucho, J. O., \& Gould, W. T. (1993). Internal Migration, Urbanization, and Population Distribution. Demographic Change in sub-Saharan Africa, 256-296.

Pazarlioglu, M. V. (2007). İzmir Örneğinde İç Göçün Ekonometrik Analizi. Yönetim ve Ekonomi. Celal Bayar Üniversitesi İktisadi ve İdari Bilimler Fakültesi Dergisi, 14(1), 121-136.

Piras, R. (2016). A Long-run Analysis of Push and Pull Factors of Internal Migration in Italy. Estimation of a Gravity Model with Human Capital Using Homogeneous and Heterogeneous Approaches. Papers in Regional Science. https://doi.org/10.1111/pirs. 12211

Song, Q., \& Liang, Z. (2016). New Patterns of Internal Migration in Emigrant - Sending Communities: the Case of China. International Migration. https://doi.org/10.1111/imig.12238

Strobl, E., \& Valfort, M. A. (2015). The Effect of Weather-induced Internal Migration on Local Labor Markets. Evidence from Uganda. The World Bank Economic Review, 29(2), 385-412. https://doi.org/10.1093/wber/lht029 


\section{Macrothink}

Business and Management Horizons

ISSN 2326-0297

2016, Vol. 4, No. 2

Tanfer, K. (1983). Internal Migration in Turkey: Socioeconomic Characteristics by Destination and Type of Move 1965-70. Studies in Comparative International Development, 18(4), 76-111. https://doi.org/10.1007/BF02686501

Winer, S. L., \& Gauthier, D. (1982). Internal Migration and Fiscal Structure: An Econometric Study of the Determinants of Interprovincial Migration in Canada. Minister of Supply and Services Canada: Available from Canadian Govt. Pub. Center, Supply and Services Canada

Wood, W. B. (1994). Forced Migration: Local Conflicts and International Dilemmas. Annals of the Association of American geographers, 84(4), 607-634. https://doi.org/10.1111/j.1467-8306.1994.tb01879.x

Yakar, M. (2012). Türkiye'de İç Göçlerin İlçelere Göre Mekânsal Analizi: 1995-2000 Dönemi. Uluslararası İnsan Bilimleri Dergisi, 9(1), 741-768.

\section{Copyright Disclaimer}

Copyright for this article is retained by the author(s), with first publication rights granted to the journal.

This is an open-access article distributed under the terms and conditions of the Creative Commons Attribution license (http://creativecommons.org/licenses/by/3.0/). 